\title{
Organic and conventional tiger nut (Cyperus esculentus): Differences in nutritional, antioxidant and microbiological properties
}

\author{
Lourdes Bosch1, María Auxiliadora Dea-Ayuela1, Hortensia Rico 2,3, Jose M. Soriano,4* \\ ${ }^{1}$ Departamento de Farmacia. Facultad de Ciencias de la Salud. Universidad CEU Cardenal Herrera. Alfara del Patriarca. Valencia. España, \\ ${ }^{2}$ Laboratorio de Microbiología. Facultat de Farmacia. Universitat de València. Burjassot. Valencia. España, ${ }^{3}$ Unidad Mixta de Investigación en \\ Endocrinología, Nutrición y Dietética Clínica. Universitat de València- Instituto de Investigación Sanitaria La Fe. Valencia. España, ${ }^{4}$ Food \& \\ Health Lab. Instituto de Ciencias de los Materiales. Universitat de València. Paterna. España
}

\section{A B S T R A C T}

\begin{abstract}
Tiger nut (Cyperus esculentus L.), also known as chufa (European sedge), is a member of the Cyperaceae family, which is used in organic and conventional agriculture for its small edible tubers and grown in temperate and tropical zones of the world being consumed raw, roasted or pressed for its juice as beverage. The aim of this study is analyzing the proximate composition (AOAC methods), total phenolic content (Folin-Ciocalteu method), total antioxidant capacity (Trolox equivalent antioxidant capacity, TEAC) and microbiological profile (International Standard Organization norms, ISO) of samples of Spanish organic and conventional, Nigerian conventional and unknown origin tiger nuts obtained from supermarkets and local markets in Spain. No significant differences in proximate composition and antioxidant properties were found between Spanish organic and conventional tiger-nuts, except in total phenolic level $(p<0.005)$. No significant differences were found in all samples about ash, lipid, total sugar and carbohydrate values, but significant differences $(p<0.005)$ were found for moisture, protein, fiber and antioxidant capacity between Spanish samples and Nigerian or unknown origin samples. No coagulase-positive staphylococci, nor Salmonella spp. were detected in any of the studied samples. Significant differences $(p<0.005)$ were found for moulds and yeasts between analysed samples, but no significant differences were detected in other microorganisms.
\end{abstract}

Keywords: Composition; Microbiology; Organic and conventional; Proximate total phenolic contents; Tiger-nut; Total antioxidant capacity

\section{INTRODUCTION}

Tiger nut (Cyperus esculentus L.) is a crop of the sedge family also known as yellow nut sedge, funeral gift, nut grass, rush nut, yellow nutgrass, Zulu nut, edible galingale, earth or ground almonds, the precious grain, the grain of the precious, souchet in French, ermandeln in German, atadwe in Ghana, cbufa in Spanish, aya, aki awnsa, ofio and isipaccara in from Nigeria. Tiger nut can be obtained from different areas including Spain (Valencia Region), Egypt, Ghana, Nigeria, Turkey, East Mediterranean, USA, Alaska, South Korea and China. It has become naturalized in many other regions, including Ukraine, China, Hawaii, Indochina, New Guinea, Java, New South Wales and various oceanic islands (Sanchez-Zapata et al., 2012; AdjeiDuodu, 2014). Tiger nut can be eaten raw or toasted and it can be ground to manufacture a popular beverage called horchata de chufa in Spain. In the bibliography, several studies of tiger nut and their products had been carried out including nutritional and organoleptic characteristics (Coşkuner et al., 2002; Bosch et al., 2005; Lasekan and Abdulkarim, 2012; Kizzie-Hayford et al., 2017), micotoxicological (Sebastià et al., 2012a; Rubert et al., 2012) and microbial analysis (Sebastià et al., 2012b; Kizzie-Hayford et al., 2016).Foods from organic agriculture constitute a segment of the growing market within the food industry. The results of the published studies comparing the composition of these products and the conventional ones are controversial (Bajgai et al., 2015; Cardoso et al., 2011; Hallmann et al., 2013). None of the studies conducted to date have compared nutritional, antioxidant and microbiological properties between organic and conventional tiger nuts from different origin.

The aim of this study is to analyse proximate composition, total phenolic contents, antioxidant capacities and microbiological

\footnotetext{
*Corresponding author:

Jose M. Soriano, Unidad Mixta de Investigación en Endocrinología, Nutrición y Dietética Clínica. Universitat de València- Instituto de Investigación Sanitaria La Fe. Valencia. España, Food \& Health Lab. Instituto de Ciencias de los Materiales. Universitat de València. Paterna. España. E-mail: jose.soriano@uv.es
} 
profiles of Spanish and Nigerian conventional, Spanish organic and unknown origin tiger nuts.

\section{MATERIALS AND METHODS}

\section{Samples and sampling procedure}

Samples of Spanish organic $(n=30)$ and conventional $(n=30)$, Nigerian conventional $(n=30)$ and unknown origin $(n=30)$ tiger nuts were collected in aseptically in sterile bottles (VWR International Eurolab, Barcelona, Spain) from supermarkets and local markets in Spain. Immediately after collection, samples were chilled to $4^{\circ} \mathrm{C}$ and transported to the laboratory for analysis. The microbiological analysis was done on the same day.

Proximate composition, total phenolic content and total antioxidant capacity

Moisture, ash, lipid, protein, total sugar, carbohydrate and fibre were determined by AOAC methods (AOAC, 1997). Total phenolic content was determined according to the adapted Folin-Ciocalteu method and total antioxidant capacity was evaluated according to the Trolox equivalent antioxidant capacity (TEAC) assay (Zielinski and Kozlowska, 2000). Each assay was carried out in triplicate.

\section{Microbiological analysis}

Samples (25 g) were weighed into sterile stomacher bags, homogenized in a Stomacher (Classic, IUL, Barcelona, Spain) and diluted with $225 \mathrm{~mL}$ buffered peptone water (BPW) (Oxoid, Unipath, Hampshire, UK). The homogenate from the sample preparation was used for the plating and incubation procedures. Four 10-fold dilutions were made with each sample, $1 \mathrm{~mL}$ of each step was inoculated in duplicate plate count agar (PCA) standard (Oxoid) at $30^{\circ} \mathrm{C}$ for 72 hours, according to the ISO 4833:2003, to determine the number of mesophilic aerobic plate counts (APC). Enterobacteriaceae, faecal coliforms, Escherichia coli, coagulase positive staphylococci, spores of Clostridium, Salmonella spp., Shigella spp., Yersinia enterocolitica and Listeria monocytogenes were carried out according to the ISO 21528-2:2004, ISO 9308-1:2000, ISO 166492:2002, ISO 6888-1:1999/Amd 1:2003, ISO 15213:2003, ISO 6579:2002, ISO 21567:2004, ISO 10273:2017 and ISO 11290-1:1996, respectively, methods. Furthermore, moulds and yeasts were determined, according to ISO 21527-1:2008 Some colonies isolated are shown in Figure 1.

\section{Statistical analysis}

Statistical analysis for comparison of origin was carried out with two-tailed paired t test (P-value). Quantified microorganisms expressed as colony-forming unit/g (CFU/g) were converted to decimal logs. Quantified parameters were treated by the Student's t-test to determine whether tiger nuts studied according to their origin differed significantly $(\mathrm{p}<0.005)$. Data were analyzed using the Statistics Package for the Social Sciences (IBM SPSS Version 12.0 software).

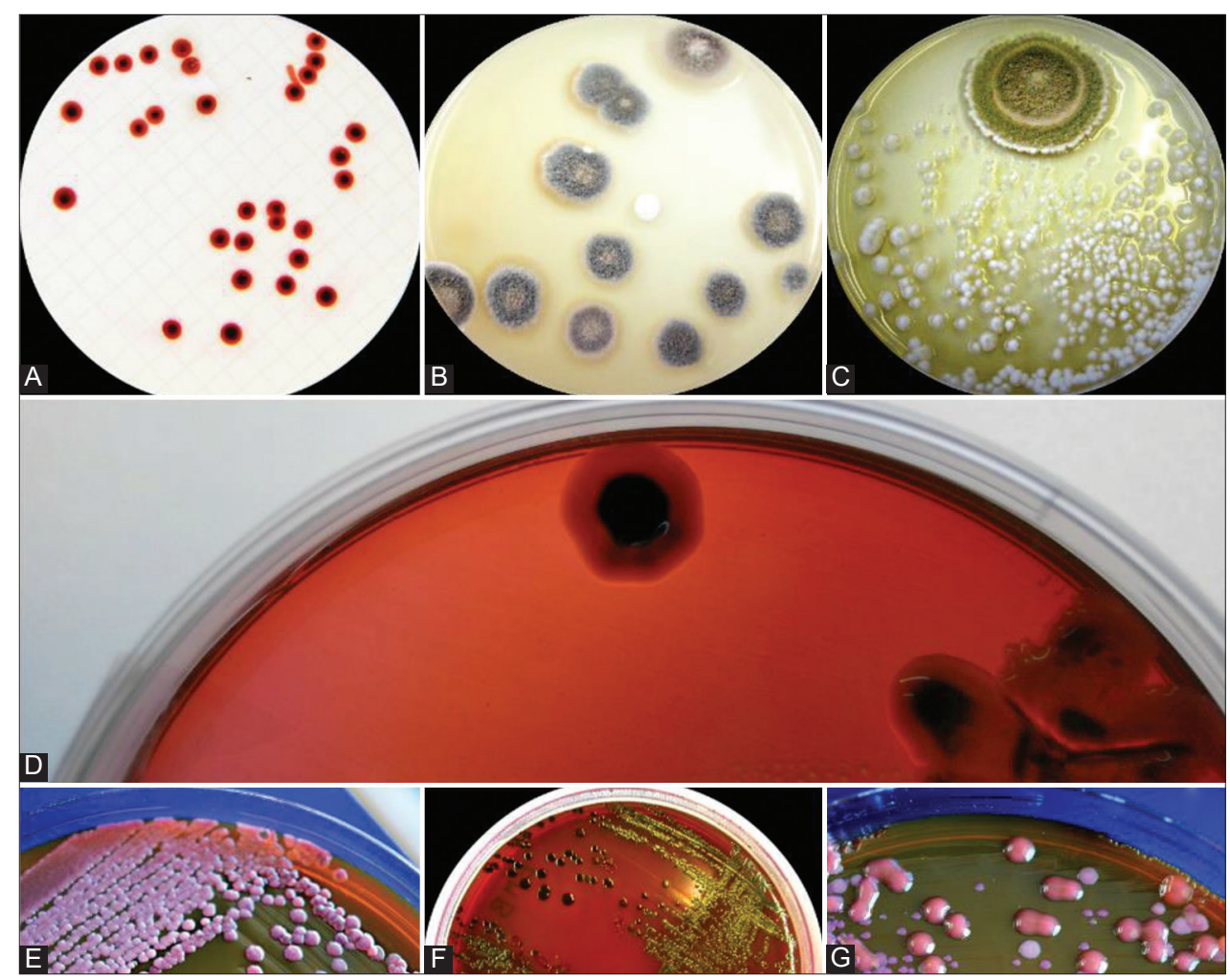

Fig 1. Colonies of (A) faecal coliforms, (B) moulds, (C) yeasts, (D) Yersinia enterocolitica, (E) Enterobacter cloacae, (F) Escherichia coli and (G) Klebsiella pneumoniae (with mucous) and Burkholderia cepacia 


\section{RESULTS AND DISCUSSION}

No significant differences were found in our study in all samples (Table 1) about ash, lipid, total sugar, and carbohydrate values. For moisture, the highest value was detected in the Spanish organic tiger nuts $(9.5 \%)$ (Table 1). The lipid content was $24.5-31.4 \%$ (Table 1). Our results demonstrated that the highest values of protein were found in Spanish tiger nut (8.5-8.9\%). The highest value of fibre was found in Spanish tiger nut (8.8-9.0\%) (Table 1). No significant differences were found in values of proximate composition and antioxidant properties between Spanish organic and conventional tiger nuts, except in total phenolic level $(p<0.005)$ (Table 1). Furthermore, significant differences $(p<0.005)$ were found for TEAC between Spanish organic tiger nut and Nigerian conventional and unknown origin tiger nut. Both latter had significant differences $(p<0.005)$ in comparison with Spanish conventional tiger nut. Tables 2 and 3 show the microbial profile in the studied tiger nuts. No coagulase-positive staphylococci, nor Salmonella spp., were detected in any of the studied samples. Significant differences $(p<0.005)$ were found for moulds and yeasts between Spanish organic tiger nut and Nigerian conventional and unknown origin tiger nut. Both latter had significant differences $(\mathrm{p}<0.005)$ in comparison with Spanish conventional tiger nut. No significant differences were found in our study (Table 2) in other analysed microorganisms.

Adel et al. (2015) analysed brown variety tiger nut tubers from local market in Fayoum province (Egypt) and observed that the proximate composition was 7.30, 2.64, 22.14, 4.33, 15.47 and $48.12 \%$ for moisture, ash, lipid, protein, fibre and carbohydrate, respectively. Adjei-Duodu (2014) studied three varieties of tiger nuts selected from Ghana (black and brown), Cameroon (yellow) and UK market (Spain) (brown) and detected that the proximate composition was 7.7-32.2, 1.6-2.1, 20.9-36.6, 3.3-6.7, 19.2, 31.2-62.9 and 50.5-82.1\% for moisture, ash, lipid, protein, fibre, total sugar and carbohydrate, respectively. Kizzie-

Table 1: Proximate composition, total phenolic contents and antioxidant capacities of studied tiger-nut

\begin{tabular}{|c|c|c|c|c|}
\hline \multirow[t]{2}{*}{ Parameter } & \multicolumn{4}{|c|}{ Origin } \\
\hline & A & B & $\mathbf{C}$ & D \\
\hline Moisture (g/100 g) & $9.5 \pm 1.0^{\mathrm{b}, \mathrm{c}}$ & $8.5 \pm 2.0$ & $7.4 \pm 1.1^{\mathrm{b}}$ & $7.1 \pm 1.0^{c}$ \\
\hline Ash $(\mathrm{g} / 100 \mathrm{~g})$ & $1.8 \pm 0.1$ & $1.9 \pm 0.2$ & $1.7 \pm 0.2$ & $1.7 \pm 0.3$ \\
\hline Lipid (g/100 g) & $29.7 \pm 5.9$ & $31.4 \pm 6.5$ & $24.5 \pm 3.8$ & $29.5 \pm 4.5$ \\
\hline Protein $(\mathrm{g} / 100 \mathrm{~g})$ & $8.5 \pm 0.9^{b, c}$ & $8.9 \pm 1.1^{\mathrm{d}, \mathrm{e}}$ & $5.1 \pm 0.9^{b, d}$ & $5.8 \pm 0.7^{c, e}$ \\
\hline Total sugar $(\mathrm{g} / 100 \mathrm{~g})$ & $15.6 \pm 0.7$ & $15.3 \pm 0.9$ & $15.4 \pm 1.8$ & $13.8 \pm 0.7$ \\
\hline Carbohydrate $(\mathrm{g} / 100 \mathrm{~g})$ & $44.1 \pm 0.6$ & $43.2 \pm 0.7$ & $40.8 \pm 0.7$ & $38.7 \pm 1.8$ \\
\hline Fiber $(g / 100 \mathrm{~g})$ & $8.8 \pm 0.5^{b, c}$ & $9.0 \pm 0.7^{e}$ & $7.8 \pm 0.9^{b}$ & $6.9 \pm 1.1^{\mathrm{c}, \mathrm{e}}$ \\
\hline Trolox equivalent antioxidant capacity (TEAC)* & $32.3 .2 \pm 2.7^{\mathrm{b}, \mathrm{c}}$ & $28.2 \pm 2.9^{\mathrm{d}, \mathrm{e}}$ & $20.1 \pm 1.6^{b, d}$ & $18.5 \pm 4.6^{\mathrm{c}, \mathrm{e}}$ \\
\hline Total phenolic (TP) level ${ }^{* *}$ & $2015.0 \pm 68.5^{\mathrm{a}, \mathrm{b}, \mathrm{c}}$ & $1800.0 \pm 45.8^{\mathrm{a}, \mathrm{d}, \mathrm{e}}$ & $1524.8 \pm 89.4^{b, d}$ & $1425.9 \pm 54.7^{\text {ce }}$ \\
\hline
\end{tabular}

A: Spanish organic tiger-nut; B: Spanish conventional tiger-nut; C: Nigerian conventional tiger nut; D: unknown origin. 'Data expressed as micromoles of Trolox equivalents per gram of tiger-nut; "Data expressed as mg gallic acid kg ${ }^{-1}$ of tiger-nut. ${ }^{a} p<0.005$ for differences between Spanish organic and conventional tigernuts; ${ }^{b} p<0.005$ for differences between Spanish organic and Nigerian conventional tiger-nuts; ${ }^{c} p<0.005$ for differences between Spanish organic and unknown origin tiger-nuts; ${ }^{d} p<0.005$ for differences between Spanish conventional and Nigerian conventional tiger-nuts; ${ }^{e} p<0.005$ for differences between Spanish conventional and unknown origin tiger-nuts.

Table 2: Quantified microbiological profile of studied tiger-nuts from different origins

\begin{tabular}{|c|c|c|c|c|c|}
\hline & & \multicolumn{4}{|c|}{ Origin } \\
\hline & & A & B & C & D \\
\hline \multirow[t]{2}{*}{ Aerobic plate count } & Log cfu/g $\pm S D$ & $4.6 \pm 0.5$ & $4.9 \pm 1.2$ & $5.3 \pm 0.8$ & $5.8 \pm 0.8$ \\
\hline & Incidence & $30 / 30$ & $30 / 30$ & $30 / 30$ & $30 / 30$ \\
\hline \multirow[t]{2}{*}{ Enterobacteriaceae } & Log cfu/g $\pm S D$ & $2.8 \pm 1.1$ & $2.3 \pm 0.9$ & $3.8 \pm 1.2$ & $3.8 \pm 1.0$ \\
\hline & Incidence & $30 / 30$ & $30 / 30$ & $30 / 30$ & $30 / 30$ \\
\hline \multirow[t]{2}{*}{ Faecal coliforms } & Log cfu/g $\pm S D$ & $1.3 \pm 0.2$ & $1.2 \pm 0.3$ & $1.9 \pm 0.2$ & $2.0 \pm 0.6$ \\
\hline & Incidence & $30 / 30$ & $30 / 30$ & $30 / 30$ & $30 / 30$ \\
\hline \multirow{2}{*}{ Escherichia coli } & Log cfu/g $\pm S D$ & $1.0 \pm 0.3$ & $1.0 \pm 0.3$ & $1.4 \pm 0.1$ & $1.5 \pm 0.6$ \\
\hline & Incidence & $30 / 30$ & $30 / 30$ & $30 / 30$ & $30 / 30$ \\
\hline \multirow[t]{2}{*}{ Coagulase-positive staphylococci } & Log cfu/g $\pm S D$ & $\mathrm{nq}$ & $\mathrm{nq}$ & $\mathrm{nq}$ & $\mathrm{nq}$ \\
\hline & Incidence & - & - & - & - \\
\hline \multirow[t]{2}{*}{ Sulphite-reducing Clostridium } & Log cfu/g $\pm S D$ & $1.2 \pm 0.1$ & $1.3 \pm 0.1$ & $1.5 \pm 0.1$ & $1.4 \pm 0.2$ \\
\hline & Incidence & $30 / 30$ & $30 / 30$ & $30 / 30$ & $30 / 30$ \\
\hline \multirow[t]{2}{*}{ Moulds and yeasts } & Log cfu/g $\pm S D$ & $1.9 \pm 0.3^{b, c}$ & $1.5 \pm 0.2^{\mathrm{d}, \mathrm{e}}$ & $2.8 \pm 0.4^{b, d}$ & $2.8 \pm 0.3^{\mathrm{c}, \mathrm{e}}$ \\
\hline & Incidence & $20 / 30$ & $20 / 30$ & $29 / 30$ & $30 / 30$ \\
\hline
\end{tabular}

A: Spanish organic tiger-nut; B: Spanish conventional tiger-nut; C: Nigerian conventional tiger nut; D: unknown origin.nq: Not quantified ${ }^{\mathrm{b}} \mathrm{p}<0.005$ for differences between Spanish organic and Nigerian conventional tiger-nuts; ${ }^{c} p<0.005$ for differences between Spanish organic and unknown origin tiger-nuts; ${ }^{d} p<0.005$ for differences between Spanish conventional and Nigerian conventional tiger-nuts; ${ }^{\mathrm{e}} \mathrm{p}<0.005$ for differences between Spanish conventional and unknown origin tiger-nuts 
Table 3: Others microorganisms detected in studied tiger-nuts

\begin{tabular}{|c|c|c|c|c|}
\hline \multirow[t]{2}{*}{ Parameter } & \multicolumn{4}{|c|}{ Number of positive samples (\%) out of thirty analyzed } \\
\hline & A & B & C & D \\
\hline Acinetobacter calcoaceticus & $25(83.3)$ & $22(13.3)$ & nd & nd \\
\hline Burkholderia cepacia & 10 (33.3) & $8(26.6)$ & nd & nd \\
\hline Citrobacter freundii & $8(26.6)$ & 7 (23.3) & $14(46.6)$ & 25 (83.3) \\
\hline Enterobacter cloacae & $1(3.3)$ & $1(3.3)$ & $9(30.0)$ & $20(66.6)$ \\
\hline Klebsiella pneumoniae & $2(6.6)$ & $3(10.0)$ & $15(50.0)$ & $18(60.0)$ \\
\hline Listeria monocytogenes & nd & nd & $1(3.3)$ & $1(3.3)$ \\
\hline Providencia rustigianii & $14(46.6)$ & $18(60.0)$ & nd & nd \\
\hline Salmonella spp. & nd & nd & nd & nd \\
\hline Shigella spp. & nd & nd & nd & $1(3.3)$ \\
\hline Yersinia enterocolitica & nd & nd & $2(6.6)$ & $3(10.0)$ \\
\hline
\end{tabular}

A: Spanish organic tiger-nut; B: Spanish conventional tiger-nut; C: Nigerian conventional tiger nut; D: unknown origin. nd: Not detected

Hayford et al. (2015) studied tiger nuts obtained from farmers in the Central Region of Ghana and observed that the proximate composition was $1.8,21.1,4.7,24.6$ and $48,1 \%$ dry mass of tiger nuts for ash, lipid, protein, total fibre and carbohydrate, respectively. Alegría-Torán and Farré-Rovira (2003) analysed Spanish tiger nuts and observed that the proximate composition was 7.1,1.7,26.1, 7.6, $11.9,15.4$ and $45.3 \%$ for moisture, ash, lipid, protein, total fibre, total sugar and carbohydrate, respectively. Ogunlade et al. (2015) analysed Nigerian dry tiger nuts and revealed that had 5.6, 12.2, 1.5, 1.6, 16.3 and $62.8 \%$ for ash, moisture, lipid, protein, total fibre and carbohydrate, respectively. Bado et al. (2015) studied three morphotypes of tiger nuts (yellow and big, yellow and small and black and big tubers) from Burkina Faso and obtained that the proximate composition was 4.99-5.19, 1.69-2.21, 24.9-28.9, $3.3-4.33,30.54-33.21$ and $64.73-69.21 \%$ for moisture, ash, lipid, protein, starch and carbohydrate, respectively.

For moisture, Morell and Barber (1983) and Frega et al. (1984) observed that values of moisture were 7.1-9.7 and 8\%, respectively, in Spanish tiger nut; while Umerie et al. (1997) and Cosskuner et al. (2002) found lower values in moisture from Nigerian (3.6\%) and Turkish (6.6-6.9\%) tiger nuts, respectively. Usually, agricultural practices consist of collecting this tuber and removing of heavy particles by gravity. After this step, tiger nuts are pre-cleaned with water showers to eliminate the superficial dust and dried to preserve their quality during the storage. This last procedure will reduce their content of moisture. The ash content was 1.7-1.9\% (Table 1). Our results are similar of the study of Temple (1988) and Temple et al. (1990). However, values reported by Umerie et al. (1997) and Addy and Eteshola (1984) on tiger nuts were significantly higher values (2.4 and 6.7\%, respectively).

In Spanish tiger nuts, values for lipids were 23.0-28.3 and 23.1\%, according to Morell and Barber (1983) and Frega et al. (1984), respectively, while Umerie et al. (1997) detected values of $29.7 \%$ in Nigerian tiger nuts. In Turkey products, values were 23.5-25.3\% (Coşkuner et al., 2002). For lipid,
Linssen et al. (1988) compared chufa and olive oils and not only found strong similarities in their fatty acid profile (mainly represented by oleic) but also in the positional distribution structure of triglycerides.

In Spanish tiger nuts, values from protein were 8.2-9.2 and $2.0 \%$ in the study of Morell and Barber (1983) and Frega, et al. (1984), respectively, while Umerie et al. (1997) detected in Nigerian tiger nuts values of $2.7 \%$. In Turkey products (Coşkuner et al., 2002), protein content was $4.2-6.2 \%$. Ogunlade et al. (2015) indicated that the values observed in crude protein were lower when compared with those reported on tiger nut by Gambo and Da'u (2014), probably due to difference in variety. In the protein fraction, which represents the most limiting component in tiger nuts, the most abundant amino acid is the arginine, which is followed by aspartic and glutamic acids. On the contrary, the most limited amino acids are methionine, tryptophan, and valine. Mean values of tiger nut amino acids showed that these tubers were not a good source of protein, neither in content nor in composition of amino acids.

For fibre, in Spanish Tiger nuts, values from fibre were 9.8-11.0 and $8.1 \%$ in the study of Morell and Barber (1983) and Frega et al. (1984), respectively, while Umerie et al. (1997) detected values of $12.9 \%$ in Nigerian tiger nuts. In Turkey products, value for fibre was $8.7 \%$ (Coskuner et al., 2002). The starch content of chufa tubers decreases and the reducing sugar (inverted sugar) content increases during storage (Coşkuner et al., 2002). The carbohydrates of chufa tuber are composed, mainly, by starch and dietetic fibre (Temple et al., 1990).

Ogunlade et al. (2015) analysed Nigerian dry tiger nuts and revealed that had 825 micromole Gallic Acid Equivalent (GAE)/g for total phenolic contents. In fact, Parker et al. (2000) observed tiger nut having phenolic acids bound to cell walls. However, this value was lower in tiger nut beverages (169.8 $\mathrm{mg}$ GAE/L) and tiger nut oil (17.9 mg GAE/kg oil) according to the study of Sanchez-Zapata et al. (2012) and Ezeh et al. (2014), respectively. 
Literature is scarce in the microbiological profiles in tiger nuts and their products. Sanchez-Zapata et al. (2012) detected aerobic mesophilic $\left(5.5 \log _{10} \mathrm{CFU} \mathrm{g}{ }^{-1}\right)$, Enterobacteriaceae $\left(2.5 \log _{10}\right.$ CFU g g $)$ and moulds and yeasts $\left(3.2 \log _{10} \mathrm{CFU}\right.$ $\left.\mathrm{g}^{-1}\right)$ in drained-water from tiger nut beverage process by products before pasteurization. However, these values after pasteurization were reduced $\left(0.9\right.$ and $0.8 \log _{10} \mathrm{CFU} \mathrm{g}{ }^{-1}$ from aerobic mesophilic and Enterobacteriaceae, respectively) and moulds and yeast were not detected. Sebastià et al. (2012b) found, in tiger nut beverages, that 67\% (16 samples) harboured total plate counts while the rest of samples were free from these microorganisms. Enterobacteriaceae were detected in $62 \%$ (15 samples). E. coli were found in only one sample (4\%), yeasts and moulds were detected in $62 \%$ (15 samples) each, Shigella was found in 21\% (five samples); however, all samples were free from S. aureus, Salmonella, Y. enterocolitica, C. perfringens, Vibrio spp. and L. monocytogenes.

\section{CONCLUSIONS}

Findings from this study suggest that total phenolic contents and antioxidant properties in Spanish tiger nuts, especially in organic ones, are higher than those in samples from other origin. However, proximate composition is less affected by origin and type of agriculture. On the other hand, values of moulds and yeasts in Spanish samples were lower than in Nigerian conventional and unknown origin tiger nut. The presence in marketplace of unknown origin should be checked to improve traceability and consumer perceptions about the safety of food.

\section{Authors' contributions}

Jose M. Soriano took samples, led the laboratory experiments and contributed to conceptualization, data analysis and writing. Lourdes Bosch, María Auxiliadora Dea-Ayuela and Hortensia Rico contributed in conceptualization, conducted laboratory experiments, assisted in data analysis and drafting the manuscript.

\section{REFERENCES}

Addy, E. O. and E. Eteshola. 1984. Nutritive value of a mixture of tigernut tubers (Cyperus esculentus L.) and baobab seeds (Adansonia digitata L.). J. Sci. Food Agric. 35: 437-440.

Adel, A. A., A. M. Awad, H. H. Mohamed and S. Iryna. 2015. Chemical composition, physicochemical properties and fatty acid profile of Tiger Nut (Cyperus esculentus L) seed oil as affected by different preparation methods. Int. Food Res. J. 22: 1931-1938.

Adjei-Duodu, T. 2014. Physical, Chemical and Functional Properties of Tiger Nuts (Cyperus esculentus) Selected from Ghana, Cameroon and UK Market (Spain) PhD Thesis, University of Plymouth, United Kingdom. Available from: https://www.pearl. plymouth.ac.uk/bitstream/handle/10026.1/3313/2014Adjeiduodu10013856phd.pdf?sequence=1\&isallowed=y. [Last accessed on 2020 Apr 11].
Alegría-Torán, A. and R. Farré-Rovira. 2003. Horchata y salud: Aspectos nutricionales y dietéticos. In: Fundación Valenciana de Estudios Avanzados. Jornada Chufa y Horchata: Tradición y Salud. Conselleria de Agricultura, Pesca y Alimentación, Valencia, Spain, pp. 55-70.

AOAC. 1997. Official Methods of Analysis of AOAC International. $16^{\text {th }}$ ed. Association of Official Analytical Chemists, Washington, DC, United States.

Bado, S., P. Bazongo, G. Son, M. T. Kyaw, B. P. Forster, S. Nielen, A. M. Lykke, A. Ouédraogo, and I. H. Bassolé. 2015. Physicochemical characteristics and composition of three morphotypes of Cyperus esculentus tubers and tuber oils. J. Anal. Methods Chem. 2015: 673547.

Bajgai, Y., P. Kristiansen, N. Hulugalle and M. McHenry. 2015. Comparison of organic and conventional managements on yields, nutrients and weeds in a corn-cabbage rotation. Renew. Agric. Food Syst. 30: 132-142.

Bosch, L., Alegría, A. and R. Farré. 2005. RP-HPLC Determination of tiger nut and orgeat amino acids contents. Food Sci. Technol. Int. 11: 33-40.

Cardoso, P. C., A. P. B. Tomazini, P. C. Stringheta, S. M. R. Ribeiro and H. M. Pinheiro-Sant'Ana 2011. Vitamin C and carotenoids in organic and conventional fruits grown in Brazil. Food Chem. 126: 411-416.

Coşkuner, Y., R. Ercan, E. Karababa and A. N. Nazlican. 2002. Physical and chemical properties of chufa (Cyperus esculentus $L$ ) tubers grown in the Çukurova region of Turkey. J. Sci. Food Agric. 82: 625-631.

Ezeh, O., M. H. Gordon and K. Niranjan. 2014. Tiger nut oil (Cyperus esculentus L.): A review of its composition and physico-chemical properties. Eur. J. Lipid Sci. Tech. 116: 783-794.

Frega, N., L. S. Conte, G. Lercker and A. Carnacini. 1984. Composizione dei tubercoli di Cyperus esculentus. Riv. Sci. Aliment. 13: 211-214.

Gambo, A. and A. Da'u. 2014. Tiger nut (Cyperus esculentus): Composition, products, uses and health benefits-a review. Bayero J. Pure Appl. Sci. 7: 56-61.

Hallmann, E., J. Lipowski, K. Marszałek and E. Rembiałkowska. 2013. The seasonal variation in bioactive compounds content in juice from organic and non-organic tomatoes. Plant Foods Hum. Nutr. 68: 171-176.

ISO 10273:2017. 2017. Microbiology of Food Chain-horizontal Methods for the Detection of Pathogenic Yersinia enterocolitica. International Organization for Standardization, Geneva, Switzerland.

ISO 11290-1:1996. 1996. Microbiology of Food and Animal Feeding Stuffs-Horizontal Method for the Detection and Enumeration of Listeria monocytogenes- Part 1: Detection Method. International Organization for Standardization, Geneva, Switzerland.

ISO 15213:2003. 2003. Microbiology of Food and Animal Feeding Stuffs-Horizontal Method for the Enumeration of Sulfite-reducing Bacteria Growing under Anaerobic Conditions. International Organization for Standardization, Geneva, Switzerland.

ISO 16649-2:2002. 2002. Microbiology of Food and Animal Feeding Stuffs-Horizontal Method for the Enumeration of Beta-glucuronidase-positive Escherichia coli. Part 2: Colonycount Technique at 44 Degrees C using 5-bromo-4-chloro3-indolyl beta-D-Glucuronide. International Organization for Standardization, Geneva, Switzerland.

ISO 21527-2:2008. 2008. Microbiology of Food and Animal Feeding Stuffs-Horizontal Method for the Enumeration of Yeasts and Moulds-Part 2: Colony Count Technique in Products with Water Activity Less than or Equal to 0, 95. International Organization 
for Standardization, Geneva, Switzerland.

ISO 21528-2:2004. 2004. Microbiology of Food and Animal Feeding Stuffs-Horizontal Methods for the Detection and Enumeration of Enterobacteriaceae-Part 2: Colony-count Method. International Organization for Standardization, Geneva, Switzerland.

ISO 21567:2004. 2004. Microbiology of Food and Animal Feeding Stuffs-Horizontal Method for the Detection of Shigella spp. International Organization for Standardization, Geneva, Switzerland.

ISO 4833:2003. 2003. Microbiology of Food and Animal Feeding Stuffs-Horizontal Method for the Enumeration of MicroorganismsColony-Count Technique at 30 Degrees C. International Organization for Standardization, Geneva, Switzerland.

ISO 6579:2002. 2002. Microbiology of Food and Animal Feeding Stuffs-Horizontal Method for the Detection of Salmonella spp. Methods for Microbiological Examination of Food and Animal Feeding Stuffs. Detection of Salmonella. International Organization for Standardization, Geneva, Switzerland.

ISO 6888-1:1999/Amd 1:2003. 2003. Microbiology of Food and Animal Feeding Stuffs-Horizontal Method for the Enumeration of Coagulase-positive Staphylococci (Staphylococcus aureus and other Species)-Part 1: Technique Using Baird-Parker Agar Medium. International Organization for Standardization, Geneva, Switzerland.

ISO 9308-1:2000. 2000. Detection and Enumeration of Escherichia coli and Coliform Bacteria-Part 1: Membrane Filtration Method. International Organization for Standardization, Geneva, Switzerland.

Kizzie-Hayford, N., D. Jaros and H. Rohm. 2017. Enrichment of tiger nut milk with microbial transglutaminase cross-linked protein improves the physico-chemical properties of the fermented system. LWT Food Sci. Technol. 81: 226-232.

Kizzie-Hayford, N., D. Jaros, Y. Schneider and H. Rohm. 2015. Physico-chemical properties of globular tiger nut proteins. Eur. Food Res. Technol. 241: 835-841.

Kizzie-Hayford, N., D. Jaros, S. Zahn and H. Rohm. 2016 Effects of protein enrichment on the microbiological, physicochemical and sensory properties of fermented tiger nut milk. LWT Food Sci. Technol. 74: 319-324.

Lasekan, O. and S. M. Abdulkarim. 2012. Extraction of oil from tiger nut (Cyperus esculentus L.) with supercritical carbon dioxide (SC- $\mathrm{CO}_{2}$ ). LWT Food Sci. Technol. 47: 287-292.

Linssen, J. P. H., G. M. Kielman, J. L. Cozijnsen and W. Pilnik. 1988. Comparison of chufa and olive oils. Food Chem. 28: 279-285.

Morell, S. and J. Barber. 1983. Chufa y Horchata: Características Físicas, Químicas y Nutritivas, Technical Report. Institute of Agrochemistry and Food Technology, Valencia, Spain.

Ogunlade, I., A. A. Bilikis and G. A. Olanrewaju. 2015. Chemical Compositions, Antioxidant Capacity of Tigernut (Cyperus esculentus) and Potential Health Benefits. Available from: http:// www.eujournal.org/index.php/esj/article/view/6532/6257. [Last accessed on 2020 Apr 11].

Parker, M. L., A. Ng, A. C. Smith and K. W. Waldron. 2000. Esterified phenolics of the cell walls of chufa (Cyperus esculentus L.) tubers and their role in texture. J. Agric. Food Chem. 48: 62846291.

Rubert, J., C. Soler and J. Mañes. 2012. Occurrence of fourteen mycotoxins in tiger nuts. Food Control. 25: 374-379.

Sanchez-Zapata, E., J. Fernández-López and J. A. Pérez-Álvarez. 2012. Tiger nut (Cyperus esculentus) commercialization: Health aspects, composition, properties, and food applications. Compr. Rev. Food Sci. Food Saf. 11: 366-377.

Sebastià, N., G. Meca, J. M. Soriano and J. Mañes. 2012a. Presence of Fusarium emerging mycotoxins in tiger nuts commercialized in Spain. Food Control. 25: 631-635.

Sebastià, N., M. El-Shenawy J. Mañes and J. M. Soriano. 2012b. Assessment of microbial quality of commercial and home-made tiger nut beverages. Lett. Appl. Microbiol. 54: 299-305.

Temple, V. J. 1988. Lesser known plant foods. In: Nutritional Quality of Plant Food. Post Harvest Research Unit, Department of Biochemistry, University of Benin, Benin City, pp. 245-274.

Temple, V. J., T. O. Ojobe and M. M. Kapu. 1990. Chemical analysis of tiger nut (Cyperus esculentus). J. Sci. Food Agric. 50: 261-263.

Umerie, S. C., N. A. N. Obi and E. O. Okafor, 1997. Isolation and characterization of starch obtained from Cyperus esculentus tubers. Bioresource Technol. 62: 63-65.

Zielinski, H. and H. Kozlowska. 2000 Antioxidant activity and total phenolics in selected cereal grains and their different morphological fractions. J. Agric. Food Chem. 48: 2008-2016. 